\title{
PENYELENGGARAAN PESANTREN SALAFIYAH SHOHIBUL QUR'AN DI KOTA KENDARI
}

\author{
The Operational of Pesantren Salafiyah Shohibul Qur'an in Kendari City \\ Oleh: Rosdiana* \\ * Peneliti pada Balai Penelitian dan Pengembangan Agama Makassar \\ Kantor J1. A. P. Petta Rani No. 72 Makassar \\ E-mail: rose-lit(a),yahoo.com
}

\begin{abstract}
Abstrak
Penelitian ini bertujuan untukmengetahui kondisipenyelenggaraanpendidikan diPesantren Salafiyah Shohibul Qur 'an Kendari. Penyelenggaraan pendidikan yang ditetapkan pondokpesantren Shohibul Qur'an adalah didasarkan pada lama seorang santri dalam menamatkan hafalannya, dan masa pembelajaran bagi program Wajar Dikdas disesuaikan dengan masa pembelajaran yang diberlakukan bagi program yang diikuti oleh santri. Kurikulum yang digunakan selain kurikulum formal,yakni kurkikulum kementerian Diknasdan kurikulum Kementerian Agama,juga menerapkan kurikulum pesantren. Metode pembelajaran yang digunakan di antaranya metode ceramah, tanyajawab, dan diskusi. Metode lain yang digunakan adalah hafalan (muhafazah), demonstrasi (praktekibadah), Muhawarah (muhadasah), sorogan (privat) dan bandongan. Sistem penilaian yang digunakan pada pondokpesantren Shohibul Quran, karena belum ada rapor, maka yangdipakai adalah buku setoran hafalan. (setiap siswa diwajibkan menghafal 1 muka (satu halaman) satu hari), jadi siswa diharapkan mampu menghafal 1 juz satu bulan. Rata-rata siswa yang ada di pondok ini sekitar 70\% mampu mencapai target hafalan tersebut. Sistem evaluasiyang digunakan adalah evaluasi harian, mingguan, maupun bulanan. Ketentuan evaluasi ini didasarkan pada pokok bahasan/tema yang telah diberikan oleh ustaz/ustazah. Respon yang ditunjukkan oleh masyarakat terhadap keberadaan Pondok Pesantren Shahibul Qur 'an sangantapresiatif baik terhadap penyelenggaraan pendidikan maupun pengembangan kemasyarakatan.
\end{abstract}

Kata Kunci: penyelenggaraan, pesantren salafiyah.

\section{Abstract}

This research aims to determine the condition the operational of education in Pesantren (the boarding school) Salafiyah Shohibul Qur 'an in Kendari. The operational ofeducational set in pesantren Shohibul Qur 'an is based on the time students in completing an occasion of recitation, and the learning forCompulsoryBasic Education program tailored to the learning applied to program followed by students. The curriculum used in addition to the formal curriculum, the Ministry of Education and curriculum of Ministry of Religious Affairs, as well pesantren curriculum. Teaching methods used include lecture method, frequently asked questions, and discussions. Another method used is recitation (muhafazah), demonstration (religiouspractice), Muhawarah (muhadasah), sorogan (private) and bandongan. The scoring system used in Pesanteran Shohibul Quran, because there is no bookreport, then used the deposit recitation (each studentis required torecitateaface(onepage)oneday), so the student should be able to recitate a juz a month. The average student at this Pesantren about $70 \%$ were able to achieve the target of memorization. Evaluation system used is the evaluation ofdaily, weekly, or monthly. The provisions of this evaluation is based on subject/theme that has been given by ustads/ustazah. Response shown by the public to the presence of Pondok Pesantren Shahibul Qur'an is very appreciative, both for the operational of education and community development.

Keywords: operational, pesantren salafiyah.

\section{PENDAHULUAN}

$\mathrm{L}$ embaga pendidikan menjadi instrumen penting dalam perealisasiannya, untuk menciptakan dan menyiapkan generasi-generasi yang nantinya mengambil peran penting bagi kelanjutan pembangunan dan kemajuan bangsa. Lembaga pendidikan agama dan keagamaan seperti madrasah dan atau pesantren bersama lembaga pendidikan lainnya mengemban tanggung jawab tersebut.

Sejarah perjalanan pendidikan di Indonesia diakui bahwa pondok pesantren sebagai pendidikan dari, oleh, dan untuk masyarakat yang umumnya diselenggarakan oleh masyarakat, memiliki akar historis yang kuat. Lembaga pendidikan yang disebut pesantren merupakan lembaga pendidikan yang tumbuh dan berkembang di masyarakat. Eksistensinya telah lama memperolah pengakuan masyarakat karena terlibat dalam upaya menceraskan kehidupan bangsa, tidak hanya dari segi moral saja, tetapi memberikan sumbangsih yang cukup signifikan dalam penyelenggaraan pendidikan.

Peningkatkan peran .pondok pesantren sebagai lembaga pendidikan masyarakat, menuntut serta kesiapan dan pengelolaan serta manajemen kurikulum dari pesantren tersebut yang terimplementasi dalam 
pembelajaran-pembelajaranyang diterapkan. Penguatan pondok pesantren dalam sistem pendidikan nasional, baik secara filosofis maupun secara historis danyuridis, maka secara aplikatif pondok pesantren salafiyah sebagai salah satu bentuk pesantren, diberi tanggung jawab untuk menyelenggarakan wajib belajar pendidikan dasar (wajar diknas) 9 tahun di samping pembelajaran kitabkitab klasik. Tanggung jawab dituangkan dalam kesepakatan bersama antara Menteri Pendidikan Nasional dan Menteri Agama melalui Surat Keputusan Bersama Nomor: 1/U/KB/2000 dan Nomor: MA/86/ 2000 tentang pondok pesantren Salafiyah sebagai pola wajib belajar pendidikan dasar sembilan tahun. Kesepakatan tersebut ditindaklanjuti dengan keputusan bersama Direktur Jenderal Pembinaan Kelembagaan Agama Islam Departemen Agama dengan Direktur Jenderal Pendidikan Dasar dan Menengah Departemen Pendidikan Nasional Nomor: E/83/2000 dan Nomor: 166/C/kep/DS/2000 tentang Pedoman Pelaksanaan Pondok Pesantren Salafiyah sebagai Pola Wajib Belajar Pendidikan Dasar.

Penetapan pondok pesantren salafiyah- sebagai penyelenggara program Wajib Belajar Pendidikan Dasar pada tahun 2000/2001 sampai tahun 2006, bahwa santri yang belum terserap dalam satuan pendidikan wajib belajar pendidikan dasar formal itu sebagian telah terjaring dalam program wajib belajar pendidikan dasar pada pondok pesantren salafiyah. Keberadaan pondok Pesantren Salafiyah yang telah lama mengakar dalam budaya bangsa dan dijadikan mitra dalam program wajar diknas dan Pesantren Salafiyah merupakan jalur perluasan akses pendidikan nasional, terutama program wajar dikdas 9 tahun.

Senada dengan arah kebijakan dan strategi Kementerian Agama Tahun 2010-2014 dalam penyelenggaraan pembangunan bidang agama, yakni "peningkatan kualitas raudhatul athfal, madrasah, perguruan tinggi agama, pendidikan agama, dan pendidikan keagamaan, dengan sasaran terwujudnya pelayanan pendidikan yang merata, bermutu dan berdaya saing, serta mampu memperkuat jati diri bangsa, yang ditandai, diantaranya:' meningkatnya akses masyarakat terhadap Madrasah Ibtidaiyah (MI), Madrasah Tsanawiyah (MTs), Pesantren Salafiyah Ula dan Pesantren Salafiyah Wustho yang bermutu. Dan meningkatnya akses masyarakat terhadap Madrasah Aliyah (MA) dan Pesantren Salafiyah Ulya bermutu.

Penyelenggaraan pondok pesantren salafiyah menarik untuk dilakukan penelitian. Salah satu diantaranya penelitian yang dilakukan oleh $\mathrm{M}$. Murtadho (2005) yang dilakukan di enam propinsi dengan judul penelitian "Penuntasan Wajar Diknas dan Ketersediaan Bahan Ajar di Pesantren Salafiah". Penelitian tersebut menyimpulkan bahwa program wajar diknas di Pesantren Salafiyah cukup diminati masyarakat di daerah penelitian.

Terdorong dari hasil penelitian tersebut penelitian sejenis dilakukan pada pondok pesantren salafiyah Shohibul Qur'an Kota Kendari Provinsi Sulawesi Tenggara untuk melihat potret pengelolaan pesantren salafiyah secara komprehensif.

Berdasarkan uraian latar belakang di atas, maka masalah yang akan diangkat dalam penelitian ini adalah bagaimana penyelenggaraan pendidikan Pesantren Salafiyah Shohibul Qur'an Kendari? Bagaimana respon masyarakat terhadap penyelenggaraan Pesantren Salafiyah Shohibul Qur'an Kendari?

Penelitian ini bertujuan untuk mengetahui kondisi penyelenggaraan pendidikan di Pesantren Salafiyah Shohibul Qur'an Kendari dan untuk mengetahui respon masyarakat terhadap penyelenggaraan pendidikan pesantren salafiyah Shohibul Qur'an Kendari. Penelitian ini diharapkan bermanfaat bagi para penyelenggara pendidikan di pesantren salafiyah dalam meningkatkan mutu dan kualitas pendidikan secara umum dan sebagai bahan masukan bagi para pengambil kebijakan dalam menentukan arah pembangunan keagamaan khususnya bidang pendidikan agama dan keagamaan. Bahkan terhadap Peneliti dan akademisi yang berminat melakukan kajian yang lebih mendalam tentang pesantren salafiyah.

\section{TINJAUAN PUSTAKA}

\section{Keberadaan Pesantren}

Secara terminologi, ${ }^{2}$ istilah pesantren sudah mengisyaratkan adanya interaksi yang harmonis antara Islam dengan budaya lokal (nusantara). Konon, "pesantren" merupakan pinjaman dari bahasa Sanse- 
kerta: sastri, yang berarti pandai membaca kitab suci. "pesantren" sendiri dimaknai sebagai tempat penganut agama Hindu dan Budha yang menyelenggarakan pembelajaran dalam rangka memahami kitab suci mereka. Dan, pada gilirannnya istilah tersebut lebih sering digunakan dan bahkan menjadi istilah khas Islam Indonesia.

Pesantren atau pondok pesantren adalah lembaga yang bisa dikatakan merupakan waijud proses wajar perkembangan sistem pendidikan nasional. Dari segi historis pesantren tidak hanya identik dengan makna keislaman, tetapi juga mengandung keaslian Indonesia. Sebab, lembaga yang serupa merupakan pesantren ini sebenarnya sudah ada sejak masa kekuasaan HinduBudha. Sehingga Islam tinggal meneruskan dan mengislamkan lembaga yang sudah ada. Tentunya tidak berarti mengecilkan peranan Islam dalam memelopori pendidikan di Indonesia. ${ }^{3}$ Pesantren dewasa ini berkembang sebagai salah satu lembaga yang melakukan pembinaan terutama dalam hal pendidikan. Sesuai dengan fungsi utamanya pada awal pertumbuhannya adalah: 1) menyiapkan santri untuk mendalami dan menguasai ilmu agama Islam (tafaqqah fiddiri), yang diharapkan dapat mencetak kader-kader ulama dan turut mencerdaskan masyarakat Indonesia, 2) dakwah menyebarkan agama Islam, dan 3) benteng pertahanan umat dalam bidang akhlak. ${ }^{4}$

\section{Pondok Pesantren Salaflyah}

Pondok pesantren salaflyah sebagai penyelenggara program Wajib Belajar Pendidikan Dasar Sembilan Tahun, mengacu pada beberapa landasan yuridis di antaranya:

a. Peraturan Pemerintah Nomor 39 Tahun 1992 tentang Peran Serta Masyarakat dalam Pendidikan Nasional

b. Instruksi Presiden Nomor 1 Tahun 1994 tentang Pelaksanaan Wajib Belajar 9 Tahun.

c. Kesepakatan bersama Menteri Pendidikan Nasional dan Menteri Agama RI Nomor 1/U/KB/ 2000 dan Nomor MA/86/2000 tentang Pondok Pesantren Salaflyah sebagai Pola Wajib Belajar Pendidikan Dasar Sembilan Tahun.

d. Keputusan bersama Dirjen Bimbaga Islam Departemen Agama dan Dirjen Dikdasmen
Departemen Pendidikan Nasional Nomor E/83/ 2000 dan Nomor 166/C/KE/DS-2000 tentang Pedoman Pelaksanaan Pondok Pesantren Salaflyah sebagai pola wajib belajar pendidikan dasar.

Penyelenggaraan program wajib belajar pendidikan dasar pondok pesantren salaflyah bertujuan untuk: mengoptimalkan pelayanan program nasional Wajib Belajar Pendidikan Dasar Sembilan Tahun melalui salah satu jalur alternatif, dalam hal ini pondok pesantren dan untuk meningkatkan peran serta pondok pesantren salaflyah dalam menyelenggarakan program wajib belajar pendidikan dasar sembilan tahun bagi para peserta didik (santri), sehingga para santri dapat memiliki kemampuan setara dan kesempatan yang sama untuk melanjutkan kejenjang pendidikan yang lebih tinggi.

Adapun yang menjadi sasaran penyelenggaraan program wajib belajar pendidikan dasar pondok pesantren salaflyah ialah:

a. Para santri pondok pesantren salaflyah dan Diniyah Salaflyah, terutama yang berusia 7-15 tahun yang tidak sedang belajar pada SD/MI atau SLTP/MTs, atau bukan tamatannya, dalam artian tidak memiliki ijazah.

b. Program ini juga terbuka/dapat diiukti oleh anggota masyarakat/santri yang berusia 7-15 tahun yang belum memiliki ijazah SD/MI atau SLTP/MTs.

Adapun jenjang pendidikan untuk program wajib belajar pendidikan dasar pada pondok pesantren salaflyah, terdiri atas dua jenjang, yaitu :

a. Salaflyah Ula atau dasar, yaitu program pendidikan dasar yang setara dengan jenjang Sekolah Dasar (SD) atau Madrasah Ibtidaiyah (MI)

b. Salaflyah Wustho atau lanjutan, yaitu program pendidikan dasar pada pondok pesantren salaflyah yang setara dengan pendidikan Sekolah Lanjutan Tingkat Pertama (SLTP) atau Madrasah Tsanawiyah (MTs).

\section{Aspek-aspek Penyelenggaraan Pondok Pesantren Salaflyah}

Hal yang tak kalah pentingnya dalam suatu penyelenggara pendidikan dalam hal ini pondok pesantren

Nurcholish Madjid. Bilik-bilik Pesantren. Jakarta: Dian Rakyat. h. 3

Jurnal Edukasi, 2007, Diversifikasi Pesantren dan Pendidikan Agama, Jakarta, Puslitbang Pendidikan Agama dan Keagamaan Badan Litbang dan Diklat Depag RI, h. 41. 
adalah elemen-elemen dalam sistem pendidikan itu perlu dikenali secara mendalam sehingga dapat difungsikan dan dikembangkan. Berdasarkan hal tersebut Kementerian Agama RI menetapkan Panduan Program Pokok Penyelenggaraan Pondok Pesantren Salafiyah, diantaranya tujuan dan sasaran, kurikulum, ketenagaan, proses belajar mengajar, evaluasi, pembiayaan, sarana pendukung pembelajaran, dan pembinaan dan monitoring.

\section{Metode Penelitian}

Penelitian ini adalah penelitian evaluatif untuk melihat penyelenggaraan pesantren salafiyah. Sifat penelitiannya adalah kualitatif, sehingga pemaparan data lebihbersifat deskriptif kualitatif. Sampel sasaran adalah pesantren salafiyah Kota Kendari. Sampel individu adalah pejabat dan pelaksana terkait pada Kantor Kementerian Agama Provinsi Sulawesi Tengara dan Kota Kendari. Komunitas pesantren sasaran penelitian, meliputi: pengurus yayasan, Pembina/Kepala Pesantren, guru dan Komite Pesantren. Data dan informasi yang ingin diperoleh dari komunitas Pesantren ialah data dan i'nformasi tentang kondisi penyelenggaraan pesantren salafiyah yang diteliti. Dan masyarakat umat Islam sekitar lokasi pesantren berada terdiri atas orangtua/wali santri, tokoh pendidik/ulama, pejabat terkait, dan akademisi umat Islam disekitar lokasi pesantren salafiyah. Data dan informasi yang akan digali adalah menyangkut respon mereka tentang pesantren yang diteliti.

Untuk menjaring data yang diperlukan dalam penelitian, ada beberapa teknik yang akan digunakan, yaitu: wawancara mendalam terhadap para informan terpilih dikalangan pesantren, pejabat instansi pemerintah terkait, dan tokoh pendidikan Islam, serta orangtua/wali santri dengan menggunakan pedoman wawancara. Observasi dengan melakukan pengamatan terbatas terhadap pengelolaan pesantren terpilih. Studi dokumentasi adalah pembacaan dan pencatatan terhadap dokumen yang terdapat pada pesantren yang diteliti maupun Kantor Kementerian Agama Provinsi dan Kota. Studi pustaka, yakni kajian literasi pada sumber-sumber bacaan yang relevan dengan topik penelitian yang dilakukan. Dan Pengedaran angket/kuesioner terutama pada masyarakat Islam sekitar lokasi pesantren berada.

Penelitian ini pada dasarnya bersifat kualitatif sehingga pengolahan data lebih mengacu kepada pegolahan data kualitatif seperti kategorisasi, reduksi, deskripsi. Data yang bersifat kuantitatif disaj ikan dalam bentuk frekuensi dan persentase. Terhadap data yang telah dianalisis dilakukan interpretasi yang relevan yang merupakan penggambaran hasil penelitian untuk kemudian dijadikan acuan dalam pengambilan kesimpulan dan perumusan rekomendasi.

\section{HASIL PENELITIAN}

\section{Sejarah Pesantren Salafiayah Shohibul Qur'an Kendari}

Pondok Pesantren Shohibul Qur'an beralamat di Jalan Pekuburan Lrg. Pesantren No. 1 Kelurahan Punggolako Kecamatan Puuwatu Kota Kendari, dengan nomor statistik 512740571603. Keberadaan pesantren Shohibul Qur'an dalam perkembangannya sejak awal pada tahun 2000 mengalami proses yang panjang sampai dewasa ini. Di mana pada awal berdirinya berawal dari keseriusan bagaimana masjid dapat makmur dan dapat membina anak yatim piatu, fakir dan miskin serta anak terlantar agar dapat mendapatkan pendidikan agama sehingga dapat menjadi manusia yang bermanfaat berguna bagi bangsa dan negara, inilah yang menjadi buah pikiran dari ketua yayasan Cerdas, yakni Tamrin, SP. MP beserta dengan pengurus yayasan lainnya, yaitu Drs. Dzakir Musakar, M.Si. Abdul Wahid Said, S.Ag, Ir. H. Abdul Madikin, M. Si beserta dengan kawan-kawan seperjuangan dalam dakwah diantaranya ustaz Muhammad Safrizal, S.Ag, Ir. Sudin Empa dan Aba Shokib duduk bermusyawarah bagaimana untuk membuat suatu lembaga pendidikan pesantren di kelurahan Punggolaka.

Penentuan nama pesantren disesuaikan dengan awal pendirian pondok pesantren yaitu untuk memakmurkan masjid dan membina anak yatim piatu, fakir dan miskin serta anak lantar nama pesantren awalnya diusulkan menjadi dua nama yaitu: Pesantren Tahfidzul Qur'an dan Shohibul Qur'an.

Dalam perkembangan akhir musyawarah disepakatilah nama Shohibul Quran yang berujuk pada julukan Rasulullah saw.' yang artinya kawan, sahabat atau orang yang mendalami Alquran untuk menguatkan keputusan musyawarah dilakukan musyawarah berikutnya dengan mengundang tokoh-tokoh masyarakat diantaranya H. Sarabani Tombili, Drs. Maswar, Muh. Nasrun, "H. Abd. Wahid, dan H.

s -, Profit Pondok Pesantren Shohibul Qur'an Kendari Sulawesi Tenggara Tahun 2010. Kendari: Pesantren Shohibul Qur'an. h. 1 
Ibrahim. Hasil musyawarah menetapkan untuk segera menjalankan aktifitas pesantren dengan meminjam fasilitas tempat Aba Shokib yang berukuran 6x9 $\mathrm{m}^{2}$ disinilah awal tempat kegiatan pesantren dengan membina +40 anak TPQ masjid Babussalam.

Oleh Kiai Abu Hamid dasar penamaan Shahibul Quran adalah: 1) untuk mencapai predikat terbaik (orang yang terbaik diantara kita adalah orang yang belajar Alquran dan mengamalkannnya), 2) mempersiapakn penolong di hari kiamat/akhirat (igraul quran painnama ya $i$ yaumul qiyamati syafial bias halibihi, artinya: bacalah Alquran karena akan datang pada hari kiamat memberi syafaat kepada orang yang memilikinya, 3) menjadi penolong bagj 10 keluarganya yang harus disiksa di neraka, siapa yang mempunyai anak hafal Alquran maka 10 keluarganya yang wajib disiksa di neraka maupun dia orang fasik karena berkah anak yg hafal Alquran, dan 4) anak bisa memberikan hadiah terbaik untuk kedua ortunya, Rasulullah saw bersabda: "barang siapa mengajarkan Alquran maka dihari kiamat nanti Allah swt memberi hadiah pakaian surga terindah kepada kedua orang tuanhya yang lebih mahal dari bumi dan isinya sehingga kedua orang tuanya bertanya kepada Allah swt mengapa aku diberi hadiah sebaik ini, inilah berkah baca Alquran dari anaknya".

\section{Kepengurusan pesantren Shohibul Qur'an}

Kepengurusan pondok pesantren Shobil Qur'an untuk tahun 2010, diantaranya: Kepala pusat pengembangan dan pengawasan pondok pesantren dan panti sosial (Ust. Muhammad Safrizal, S.Ag), Dewan Pengasuh (Ust. Abu Hamid, Ust. H. Laode Aly Abdillahy, dan Ust. H. Ahmad Al Qadri), Wakil Ketua I Bidang Pendidikan Diniyah dan I'dadiyah (Ust. Nurul Huda, S.Ag), Wakil Ketua II Bidang Tahfidzul (Ust. Ahmad Khairi), Kepala program pesantren dan panti sosial Al Fitrah (Ir. Sudin Empa), Koordinator keuangan (Aba Shokib), Koordinator penyelenggara keterampilan dan wirausaha (Syafril Edy, SE), Koordinator sarana prasaranaPembangunan/arsitektur (Abdul Salam, ST), dan Staf (Muh. Nasrun, Yuliana, Drs. Maswar, Hidayatullah W, Arnaldo, Nurul Arifah, Jaisman, dan Aulia Al Qadri).

\section{Santri}

Santri merupakan elemen penting dalam sebuah pesantren, sebagai bagian penting dalam membangun pesantren harus ada murid yang datang untuk belajar. Tradisi pesantren biasanya santri terdiri dari dua kelompok, yakni santri mukim dan santri kolongan. Santri mukim yaitu murid-muridyangberasal dari daerahyang jauh dan menetap dalam kelompok pesantren. Sementara Santri kolongan adalah yang tinggal di sekitar pesantren yang tidak menetap di pesantren.

Setiap santri yang memasuki Pesantren Shohibul Qur'an diwajibkan mengikuti testing masuk yang meliputi pelajaran membaca dan menulis Alquran, tajwid, dan hafalan surah-surah pendek. Di samping itu, diadakan wawancara untuk mengetahui latarbelakang sosial orang tua, motivasi masuk pesantren dan harapan belajar di pondok pesantren.

Berdasarkan data santri pondok pesantren shohibul Qur'an dari berbagai program, diantaranya:

a. Alumni pesantren Shohibul Qur'an adalah: 60 santri (terdiri 40 laki-laki dan 20 perempuan). Keberadaan alumni dari Shohibul Qur'an sendiri ada yang melanjutkan pendidikan ke Jawa, Kalimantan, dan Sulawesi. Ada juga alumni yang mengabdikan dirinya di pondok-pondok pesantren dan bekerja.

b. S antri yang bermukin/tinggal di pondok pesantren sebanyak 60 santri yang terdiri 35 santri perempuan dan 25 santri laki-laki. Asal santri yang mukim/mondok pada pesantren Shobul Quran berasal dari berbagai wilayah di kota Kendari maupun dari luar kota Kendari bahkan terdapat santri yang berasal dari luar provinsi seperti Nabire, F lores, dll.

c. Program paket A, B, C secara keseluruhan adalah 200 orang.

d. Program diniyah sebanyak 80 santri, yang terbagi pada 3 kelas yakni kelas pagi (kelas A) dan kelas sore (kelas B dan kelas C)

e. Program TPQ sebanyak 20 santri.

\section{Tenaga Pendidik dan Kependidikan}

Secara bertahap, pemerintah telah melakukan berbagai upaya peningkatan kualitas/kompetensi guru dan tenaga kependidikan lainnya. Menurut PP No. 19 Tahun 2000 tentang Guru, bahwa guru yang berkualitas memiliki tingkat kompetensi dan kualifikasi akademik tertentu. Kompetensi guru merupakan seperangkat pengetahuan, keterampilan, dan perilaku yang harus 
dimiliki, dihayati, dikuasai, dan diwujudkan oleh guru dalam melaksanakan tugas keprofesionalan. Sementara, kualifikasi akademik guru ditunjukkan dengan ijazah yang merefleksikan kemampuan yangrdipersyaratkan bagi guru untuk melaksanakan tugas sebagai pendidik pada jenjang, jenis, dan satuan pendidikan atau mata pelajaran yang diajarkan. Tenaga yang dibutuhkan dalam program wajib belajar pendidikan dasar di pondok pesantren salafiyah adalah guru mata pelajaran bahasa Indonesia, guru mata pelajaran Matematika, dan guru mata pelajaran IPA. Untuk guru pembimbing mata pelajaran umum lainnya, dapat dilakukan oleh guru mata pelajaran umum tersebut, atau guru/ustaz pondok pesantren. Untuk meningkatkan kemampuan dan profesionalitas guru, khususnya guru dilingkungan pondok pesantren dapat mengupayakan kerjasama dan menjalin kemitraan dengan pimpinan sekolah/madrasah atau guru-guru yang terdapat pada sekolah/madrasah/pondok pesantren lain, selain itu pihak pengurus pesantren perlu mengupayakan keikutsertaan guru-guru tersebut dalam pelatihanpelatihan pendidikan guru baik yang diselenggarakan pemerintah daerah, Kementerian Agama atau Kementerian Pendidikan Nasional, maupun oleh organisasi pendidikan.

\section{Tabel 1}

\section{Jumlah Tenaga Pendidik dan Kependidikan Pesantren Shohibul Qur'an}

\begin{tabular}{|c|l|c|l|l|}
\hline NO & \multicolumn{1}{|c|}{ NAMA } & UMIIR & $\begin{array}{c}\text { PENDIDIKAN } \\
\text { TERAKHI R } \\
\text { Gontor }\end{array}$ & JURUS AN \\
\hline 1 & Kiai. Abu Hamid & $60 \mathrm{dm}$ & - \\
\hline 2 & Muh. Safiizal.SAg & $36 \mathrm{din}$ & IAIN Alauddin Kendari & Pendidikan \\
\hline 3 & Ir. Sudin Empa & $41 \mathrm{dm}$ & Univ. Haluoleo & Agronomi \\
\hline 4 & Amaldo, S.Pd & $30 \mathrm{thn}$ & Univ. Haluoleo & PKn \\
\hline 5 & Jaisman, S.Pd & 31 thn & STAIN Kendari & Pend. Agama \\
\hline 6 & Nurul Huda, S.Ag & 37 thn & LAIN Makassar & Syari ah \\
\hline 7 & Ahmad Khoiri & 30 thn & SMU & - \\
8 & Muh. Nusron & 24 thn & SMU & - \\
\hline 9 & Muh. Nasrun & 39 thn & SGO & - \\
\hline 10 & Hidavatullah Wasiah & 55 thn & MA & - \\
11 & Nurul Arfah & $20 \mathrm{dm}$ & MA & - \\
\hline 12 & Ahlia Al Qidri & $33 \mathrm{dm}$ & MA & - \\
\hline
\end{tabular}

Sumber Data: Pesantren Shohibul Quran 2010

\section{Sumber Pembiayaan}

Dalam pengelolaan program pendidikan pondok pesantren salafiyah dalam rangka menuntaskan wajib belajar pendidikan dasar sembilan tahun pada dasarnya menjadi tanggung jawab pondok pesantren dan masyarakat, sebagaimana pendidikan swasta lainnya. Sebagai lembaga pendidikan yang menyelenggarakan program wajib belajar pendidikan dasar, pondok pesantren salafiyah berhak menerima bantuan dan pembinaan dari pemerintah, baik Pemerintah Daerah,
Kementerian Agama Pusat, Kantor Wilayah di Propinsi atau Kantor Kementerian Agama di Kabupaten/Kota.

Untuk perkembangan pondok pesantren tunjangan dana sebagai penopang dalam proses belajar mengajar selama ini telah memperoleh bantuan dari berbagai pihak diantara bantuan-bantuan yang pernah diterima pesantren Shohibul Qur'an di antaranya:

a. Bantuan dari Departemen Agama:

- Dana imbalan swadaya pada tahun 2003 sejumlah Rp. 30 juta (yang diperuntukkan bangunan kantor dan ruang belajar)

- $\quad$ BOP (Bantuan Oprasional Pendidikan): masing-masing 2 kali penerimaan sebesar Rp. 5 juta pada tahun 2005 dan tahun 2007.

- BOS (Bantuan Operasional Siswa): diterima sejak tahun 2005 hingga 2009 persiswa Rp 1.235.000/persiswa.

b. Bantuan dana Dinas Sosial

Subsidi makanan (masing-masing siswa menerima 2.250/siswa, siktar 16 juta/tahun.

Alat dapur pada tahun 2009 berupa panci, kompor, dll

c. Sumbangan dari dermawan: pada tahun 2010 sudah ada donator tetap sekita 15 orang yang terdaftar. Kisaran dana tersebur Rp. 10.000 hingga 50/000 bahkan lebih tergantung kesediaan dari donator.

d. Usaha-usaha lain yang dianggap halal, yakni berupa pengembangan industri makan ringan berupa keripik nangka oleh santri.

Dukungan dana dari berbagai pihak tersebut cukup memadai bagi pesantren Shohibul Qur'an. Meski pemenuhan dan peningkatan dana tersebut terus diupayakan terutama pembiayaan terhadap kesejahteraan para pengelola khususnya kiai/ustaz. Pembiayaan pada aspek ini oleh pihak pesantren masih mengandalkan berbagai pihak khsusunya dukungan dari berbagai donator dan sumber pembiayaan lain.

\section{Sistem Pembelajaran Pondok Pesantren Shohibul Qur'an}

\section{Masa Pembelajaran}

Ketentuan pembelajaran yang ditetapkan pondok pesantren Shohibul Qur'an adalah sesuai dengan jadwal akademik pesantren. Jadwal pembelajaran yang telah ditetapkan adalah jadwal pembelajaran pada pagi hari di mulai pada jam 07.30 
sampai jam 10.30. Kemudian dilanjutkan pada jam 15.30 sampai jam 17.00 dan jadwal pembelajaran ba'da Isya.

Masa pembelajaran yang digunakan pada pondok pesantren Shohibul Qur'an adalah didasarkan pada lama seorang santri dalam menamatkan hafalan yang diperoleh oleh santri bersangkutan. Masa pembelajaran yang dilalui santri adalah 3 sampai 5 tahun, dalam masa ini oleh beberapa siswa dijalani dengan mampu menamatkan hafalan Alquran-nya yang diantara alumni dijalani dalam masa 3 tahun dan ada juga yang menambahnya satu tahan untuk memperlancar hafalan yang dimiliki oleh santri.

Di samping itu, masa pembelajaran bagi program wajar dikdas disesuai dengan masa pembelajaran yang diberlakukan bagi program yang diikuti oleh santri bersangkutan.

\section{Kurikulum}

Pada Undang-Undang Nomor 20 Tahun 2003 tentang Sistem Pendidikan Nasional pada Bab I pasal 1 ayat 9 menetapkan bahwa "kurikulum' adalah seperangkat rencana dan pengaturan mengenai tujuan, isi, dan bahan pelajaran serta cara yang digunakan sebagai pedoman penyelenggaraan kegiatan pembelajaran untuk mencapai tujuan pendidikan tertentu". ${ }^{8}$ Dalam sistem pendidikan Islam, kurikulum dikenal dengan istilah "marthaf artinya jalan terang. Makna tersirat dari jalan terang tersebut menurut al-Syaibany adalah jalan yang harus dilalui oleh para pendidik dan anak didik untuk mengembangkan keterampilan, pengetahuan, dan sikap mereka.'

Kurikulum pondok pesantren dikembangkan dalam kerangka dasar untuk meletakkan santri sebagai subjek pengetahuan. Kurikulum pondok pesantren sudah saatnya diorientasikan pada konsepsi dasar bahwa santri adalah yang pertama dan utama dalam pendidikan. Ia adalah subjek yang menjadi pusat kegiatan pendidikan karena santri mempunyai potensi, kemampuan, dan kekuatan untuk berkembang. Dalam konsepsi ini, kurikulum pondok pesantren diarahkan kepada membina santri secara utuh bukan saja segi fisik dan intelektual tetapi juga segi sosial dan afektif (emosi, sikap, perasaan, dan lain-lain). ${ }^{10}$ Mata pelajaran umum yang diwaj ibkan untuk diajarkan dan disertakan dalam pengajaran pondok pesantren adalah 3 mata pelajaran yaitu, Bahasa Indonesia, Matematika, dan Umu Pengetahuan Alam (IPA). Sedangkan mata pelajaran umum lainnya, seperti Pendidikan Kewarganegaraan, Ilmu Pengetahuan Sosial dan Bahasa Inggris atau asing, penyampaiannya dilakukan melalui penyediaan buku-buku perpustakaan dan sumber belajar lainnya atau melalui bimbingan dan penugasan.

Dalam proses pembelajaran yang dilakukan pada pondok pesantren salaflyah Shohibul Qur'an juga menggunakan kurikulum sebagai acuan. Kurikulum sebagai perangkat pembelajaran dalam menunjang proses belajar mengajar untuk mencapai seam tujuan sebagaimana tujuan yang ingin dicapai oleh pondok pesantren adalah mewujudkan santri yang mampu menghafal Alquran dan mengamalkannya dalam kehidupan sehari-hari serta mampu menjadi dai dan daiyah di tengah-tengah masyarakat.

Kurikulum yang digunakan oleh pondok pesantren Shohibul Qur'an selain kurikulum formal, yakni kurkikulum kementerian Diknas dan kurikulum Kementerian Agama, juga memerapkan kurikulum pesantren.

Kurikulum yang selama ini digunakan oleh ponpes Shohibul Qur' an adalah kurikulum pesantren Shohibul Qur'an itu sendiri. Beberapa mata pelajaran yang diberikan pada santri-santri tentunnya dominan mata pelajaran yang berkaitan dengan Alquran sesuai dengan dasar pendirian pesantren yakni mengasilkan santrisantri yang hafal Alquran. Pemberlakuan jam pelajaran bagi santri yakni jam belajar pagi dan jam belajar malam. Berikut adalah mata pelajaran yang menjadi program pesantren Shohibul Qur; an pada pagi hari dan malam (ba'da Isya) dapat dilihat pada tabel 2 dan 3.

Tabel 2

Mata Pelajaran Ponpes Shohibul Qur'an pada Jam Pagi

\begin{tabular}{|c|l|ll|ll|}
\hline NO & HARI/JAM & $07.30-0830$ & $09.00-10.00$ & $10.00-10.30$ & $15.30-17.00$ \\
\hline 1 & Sabtu & Adab/sunnah & Mufrodat & Baca Alquran & Baca Alquran \\
\hline 2 & Ahad & Tauhid & Mufrodat & Baca Alquran & Baca Alquran \\
3 & Senin & Fiqih & R Arab & Baca Alquran & Baca Alquran \\
\hline 4 & Selasa & Fiqih & B.Arab & Baca Alquran & Baca Alquran \\
5 & Rabu & Tajwid & B. Inggris & Baca Alquran & Baca Alquran \\
6 & Kamis & Dakwah Nubuwwah & R Inggris & Baca Alquran & Baca Alquran \\
\hline
\end{tabular}

Sumber Data: Pondok Pesantren Shohibul Quran

Hidayatullah Wasiah (Ustazah/pengurus santri putri). Wawancara. Di Asrama Putri Shohibul Qur'an. Rabu 13 Oktober 2010.

' Departemen Agama RI., 2003. Undang-Undang Republik Indonesia Nomor 20 Tahun 2003 tentang Sistem Pendidikan Nasional.

'A. Malik MTT. 2008. Inovasi Kurikulum Berbasis Lokal di Pondok Pesantren. Jakarta. Balai Penelitian dan Pengembangan Agama. h.25

${ }^{10}$ Makalah workshop peningkatan kapasitas pondok pesantren tgl 13 s.d 15 Mei 2009, Pedoman Pengembangan Kurikulum Pondok Pesantren Salaflyah, Jakarta, Hotel Milineum. h. 3 
Jadwal pembelajaran yang diberlakukan untuk santri laki-laki dan santri perempuan adalah sama terkecuali pada mata pelajaran dakwah nubuwwah. Pada mata pelajaran dakwah nubuwwah adalah program yang diperuntukkan bagi santri laki-laki berupa program pembelajaran dakwah bagi santri laki-laki. Dakwah yang dilakukan adalah dengan cara berkunjung ke masjid-masjid untuk berceramah dan biasanya dilakukan pada malam sabtu, di samping ceramah yang dilakukan juga menjadi imam shalat fardhu maupun shalat tarwih. Bentuk-bentuk kegiatan lain yang sering dilakukan adalah pengajian-pengajian pada saat takziah maupun syukuran-syukuran yang dilakukan oleh masyarakat sekitar pondok maupun yang berada di wilayah Kendari.

\section{Tabel 3}

\section{Mata Pelajaran Ponpes Shohibul Quran pada Jam Malam (ba'da Isya)}

\begin{tabular}{|cl|l|l|}
\hline NO & HARI & $\begin{array}{c}\text { MATA } \\
\text { PELAJARAN }\end{array}$ & \multicolumn{1}{|c|}{ GURU } \\
\hline 1 & Sabtu & Tajwid & Ahmad Khori \\
2 & Ahad & Aqidah & Kiai Abu Ham-id \\
3 & Senin & Fiqih & Kiai Abu Hamid \\
4 & Selasa & B.Arab & Nurul Huda \\
5 & Rabu & Akhlak & Muh.Safrizal \\
6 & Kamis & Terjemah & Nurul Huda \\
\hline
\end{tabular}

Tabel 2 dan 3 di atas merupakan program yang wajib di ikuti oleh santri pondok pesantren shohibul Qur'an baik pada pagi hari maupun malam hari (ba'da isya) selama seminggu kecuali hari jumat. Kegiatan pada hari jumat digunakan oleh santri dan pengasuh pondok (ustaz) dengan melakukan kegiatan Jumat bersih pada pagi hari, dan seterusnya bada Jumat kegiatan dilanjutkan dengan membaca Alquran sampai tamat, proses kegiatan membaca Alquran sampai tamat ini biasanya di bagi perkelompok satu kelompok terdiri dari 3 sampai 4 santri, biasanya sampai 10 kelompok. Satu kelompok biasanya menamatkan sampai 3 jus dan bagi santri yang lancar dan hafal Alquran biasanya bisa membaca sampai 5 jus."

Di samping itu, pondok pesantren Shohibul Qur'an memiliki sistem yang mewajibkan bagi santrinya untuk memiliki kemampuan dasar menghafal Alquran.
Diantara surah-surah hafalan wajib santri Shohibul Qur'an adalah: surah Yasin, surah Al-Mulk, ArRahman, Al Waaqi'ah, dan Surah As Sajdah.

Dalam menghasilkan santri yang hafal Alquran sesuai dengan dasar dan tujuan dari pendirian pondok pesantren Shohibul Qur'an, salah satu sistem pembelajaran yang dilakukan pada santri adalah sistem "hafalan satu muka"m. Hafalan-hafalan yang telah dilakukan oleh santri distor pada ustaz/ustazah yang telah ditentukan, dengan cara menghadapkan hafalannnya di depan ustaz/ustazah.

Kegiatan pembelajaran santri dan aktivitas santri di pesantren Shohibul Qur'an, tergolong sangat padat. Hampir tidak ada waktu senggang bagi santri untuk melakukan kegiatan lain. Kegiatan-kegiatan di luar jam pembelajaran seperti shalat lail, shalat berjamaah di setiap waktu, dan shalat-shalat sunnat lainnya, ibadahibadah lainnnya juga menjadi rutinitas bagi santri.

\section{Materi/kitab}

Beberapa materi/kitab yang digunakan pada pesantren Shohibul Qur'an diantaranya: Pengantar ilmu tajwid, Fiqih (Mabadiul fiqiyah oleh imam Syafii), Terjemah Lafziah (model dari Hidayatullah yang diperuntukkan untuk santri yang mukim), Ta'limul Muta'alim, Durusul logah, Tafsir Jalalain, Fathul muin, Safinah Tun Najah, Adab keseharian, dan Sejarah rasul dan sahabat.

\section{Metode Pembelajaran}

Pada dasarnya proses belajar mengajar pada pondok pesantren salafiyah penyelenggaraan program wajib belajar pendidikan dasar disesuaikan dengan proses pembelajaran di pondok pesantren. Prinsip dasar proses belajar mengajar ialah dapat dipahaminya bahan dan materi pelajaran tersebut oleh para santri/peserta didik, dengan lebih mudah dan lebih cepat. Metode pendidikan yang telah menjadi ciri khas pengajaran pondok pesantren dapat digunakan untuk pelaksanaan program ini. Metode-metode pengajaran tersebut antara lain: ${ }^{13}$ weton/bandongan, sorogan, halaqah, hapalan, sistem majelis taklim (musyawarah/ munazharah), dan metode ceramah. ${ }^{14}$

\footnotetext{
Hidayatullah Wasiah (Ustazah/pengurus santri putri). Wawancara. Di Asrama Putri Shohibul Qur'an. Rabu 13 Oktober 2010

"Hafalan satu muka adalah sistem pembelajaran yang berlakukan pada santri pondok pesantren Shohibul Qur'an yang mewajibkan santri menghafal Alquran satu halaman perhari.

Panduan Teknis Pondok Pesantren Salafiyah, 2004. Jakarta. Depatemen Agama RI

" Kementerian Agama RI, 2005. Pola Pengembangan Pondok Pesantren, Edisi revisi. Direktorat Jenderal Kelembagaan Agama Islam Direktorat Pendidikan Keagamaan dan Pondok Pesantren. h.47
} 
Dalam proses belajar mengajar banyak metode pembelajaran dapat dikembangkan oleh guru. Menurut Martinis Yamin metode pembelajaran merupakan cara melakukan atau menyajikan, menguraikan, memberi contoh, dan memberi latihan isi pelajaran kepada siswa untuk mencapai tujuan tertentu, diantara metodemetode tersebut adalah: metode ceramah, demonstrasi, tanya jawab, diskusi, studi mandiri, bermain peran, tutorial, pemecahan masalah, dan lain-lain."

Metode pembelajaran dalam penggunaannya tentunya disesuaikan dengan materi yang diajarkan, pesantren Shohibul Quran yang pada dasarnya adalah membinaan santri hafal Alquran tentunya metode yang digunakan adalah metode-metode sekaitan dengan pelajaran Alquran. Menurut Ustaz Safrijal ${ }^{16}$ di samping metode ceramah, tanya jawab, diskusi pada pembelajaran beberapa metode lain yang digunakan antara lain:

a. Metode hafalan (muhafazah). Yaitu suatu kegiatan belajar dengan cara menghafal suatu teks tertentu/ Alquran kemudian dihafalkan di depan ustaz. Cara mengevaluasi hafalan tersebut adalah setiap kali tatap muka apabila hafalan santri baik maka dibolehkan untuk melanjutkan hafalannya, jika belum baik diharuskan untuk mengulang hingga bacaan dan hafalan tersebut lancar dan benar.

b. Demonstrasi (praktek ibadah). Metode ini dilakukan secara perorangan atau kelompok di bawah bimbingan ustaz di dalam pelaksanaan praktek-praktek ibadah. Teknik evaluasi yang digunakan pada metode ini adalah dengan memberika kesempatan kepada siswa secara perorangan untuk melakukan demonstrasi terhadap materi ibadah yang dilakukan oleh santri, serta mengevaluasi sikap yang dilakukan santri ketika mengerjakan ibadah.

c. Muhawwarah (muhaddasah). Muhaddasah: bagian bercakap bahasa Arab atau dan menyampaikan pidato/ceramah. Penerapan metode ini adalah dengan mengamati percakapan santri ketika dalam proses belajar maupun sesama santri serta menilai kualitas jawaban santri ketika ditanya oleh ustaz. Metode muhawwarah dilakukan agar santri lancar dan fasih dalam percakapan baik pada kiai kepada para santri selama mereka menetap di lembaga pendidikan pesantren maupun di luar pesantren.

Metode-metode lain yang umumnya digunakan oleh pondok pesantren salafiyah adalah, menurut Kiai Abu Hamid: ${ }^{17}$ penggunaan metode sorokan (privat) adalah metode dimana teknik yang digunakan adalah santri saling bergilir membahasa satu pokok masalah kalau sudah selesai santri yang lain yang maju kehadapan ustaz, biasanya kitab-kitab yang bahasa adalah kitab-kitab kecil yang pembahasannya satu fasal-satu fasal.

Metode bandongan digunakan seperti pada pembelajaran yang dilakukan pada bulan Ramadhan (kuliah kilat). Biasanya kitab-kitab besar. Kitab-kitab tersebut full dipelajari 24 jam, hanya istirahat shalat dan makan. Waktunya yang singkat tersebut diefektikan dengan padat seperti mempelajarai kitab Ihya Ulumuddin, yang pada dasarnya dipelajari sampai 3 tahun hanya selesai dalam masa 40 hari selama ramadhan. Dan metode wetonan seperti (mempelajari satu kitab fiqih fasal demi fasal, misalnya fasal shalat selesai, lanjut fasal puasa, fasal zakat, fasal haji, dst). Jangka waktu tidak ditentukan sampai selesai kitab besar atau kitab kecil yang dipelajarai tersebut.

Sementara sistem penilaian yang gunakan pada pondok pesantren Shohibul Qur'an belum adanya rapor, yang ada hanya buku setoran hafalan (semampu siswa yang di wajibkan pada siswa untuk menghafal 1 muka (satu halaman) satu hari, jadi siswa di harapkan mampu menghafal 1 juz satu bulan Rata-rata siswa yang ada di pondok sekitar $70 \%$ mampu mencapai hafalan ini.

\section{Evaluasi Pembelajaran}

Untuk menilai hasil belajar santri atas tujuan-tujuan khusus yang telah ditentukan, maka diadakan evaluasi. Evaluasi ini disebut juga evaluasi hasil belajar mengajar. Dalam evaluasi ini disusun butir-butir soal untuk mengukur pencapaian tiap tujuan khusus yang telah ditentukan. Untuk tiap tujuan khusus minimal disusun satu butir soal.

Evaluasi belajar untuk santri pondok pesantren yang diikutkan dalam program wajib belajar pendidikan dasar dilakukan melalui:

\footnotetext{
Martinis Yamin, 2008. Desain Pembelajaran Berbasis Tingkat Satuan Pendidikan, Cet.2 Jakarta. Gaung Persada Press, h.152

${ }^{16}$ Muh. Safrijal, S.Ag (Pimpinan Pondok Pesantren Salafiyah Shohibul Qur'an). Wawancara. Di Pondok Pesantren Shohibul Qur'an. Selasa, 12 Oktober 2010

Kiai Abu Hamid (pengasuh pondok pesantren Shohibul Qur'an Kendari). Wawancara. Di Pondok Pesantren Shohibul Qur'an. Selasa, 12 Oktober 2010.
} 
Pelaksanaan evaluasi belajar dilakukan oleh guru/ tutor/mudarris/ustaz pondok pesantren penyelenggara selama proses pembelajaran sesuai dengan kemajuan santri dalam belajar. Bahan evaluasi harian atau mingguan bisa digunakan Lembar Kerja Santri (LKS) yang penyusunannya dipadukan dengan dengan buku paket siswa.

Ulangan umum yang merupakan penilaian prestasi belajar santri yang dilakukan secara berkala, penyelenggaraannya dapat dilakukan bersamaan waktunya dengan ulangan umum MTs atau SLTP setempat. Atau dilakukan penyelenggaraannya sesuai dengan jadwal kegiatan ulangan umum pada pondok pesantren.

Evaluasi belajar tahap akhir mata pelajaran umum, yaitu Bahasa Indonesia, Matematikan dan IPA, dengan standar nasional, akan dilakukan oleh pihak yang berwenang melakukan pengujian yaitu pusat pengujian pada Departemen Pendidikan Nasional. Ujian mata pelajaran umum lainnya dilakukan sendiri oleh guru/uztaz pondok pesantren.

Waktu penyelenggaraan bisa dilakukan dengan dua alternatif: 1) EBTA pesantren salafiyah dilakukan bersamaan dengan penyelenggaraan EBTA/EBTANAS di MTs dan SLTP setempat, 2) dilakukan bersamaan dengan waktu ujian/ imtihan pondok pesantren.

Dalam mendukung keberhasilan pembelajaran yang dilakukan pada pondok pesantren Shohibul Qur'an menentukan sistem pembinaan bagi tenaga pengajar dan sistem evaluasi bagi santri. Sistem pembinaan bagi tenaga pengajar/ustazah di upayakan dalam rangka peningkatan kualitas akademik pengajar/ ustazah tersebut. Hal ini dilakukan oleh pimpinan pesantren yang dibantu oleh masing-masing ustaz/ ustazah.

Sistem evaluasi yang dilakukan pada santri adalah sebagai upaya untuk melihat dan mengetahui sampai sejauh mana tingkat penguasaan santri terhadap pembelajaran yang telah diberikan. Sistem evaluasi yang gunakan adalah evaluasi harian, mingguan, maupun bulanan. Ketentuan evaluasi ini didasarkan pada pokok bahasan/tema yang telah diberikan oleh ustaz/ustazah.

\section{Peran dan program}

Pesantren sebagai lembaga yang tumbuh di masyarakat dalam eksistensinya menuntut berbagai pihak untuk terlibat dalam tumbuh kembang pesantren tersebut. Dari hasil respon masyarakat terhadap ponpes Shohibul Quran menunjukkan bahwa pada aspek peran pondok pesantren Shohibul Qur'an secara kelembagaan oleh kiai, santri senior telah melakukan kegiatan pengajian, ceramah agama, dan tabliq, baik di dalam pesantren maupun dilingkungan pesantren. Dan sebagain masyarakat juga menunjukkan kecenderungan bahwa peran lain dari sebuah ponpes hanya terfokus pada proses pendidikan.

Pada aspek peran pengembangan sumber daya manusia, kecendeungan masyarakat yang ada disekitar ponpes bahwa peran pengembangan SDM dilakukan pada sasaran masyarakat luar pesantren, seperti melakukan pembinaan pada kelompok-kelompok yang ada di masyarakat, remajabinaan, dll. Di samping itu, peran lain yang diketahui oleh masyarakat adalah bahwa ponpes juga memiliki peran sebagai wadah pelatihan kepada pihak lain yang ingin mengetahui sistem pengelolaan pondok pesantren salafiyah dengan cara menerima tenaga PKL, magang dan semacamnya.

Selain itu peran-peran lain yang ditunjukkan oleh masyarakat bahwa pesantren juga memiliki peran dalam memobilisasi masyarakat dalam perkembangan keagamaan dominan masyarakat mengetahui bahwa ponpes juga sebagai penyelenggara penerima zakat, infak, dan shadaqah. Peran lain yang ketahui oleh masyarakat bahwa pesantren juga sebagai penyelenggara shalat idul fitri dan idul adha.

Sebagaian masyarakat di sekitar pondok pesantren juga menganggap bahwa peran pesantren juga berfungsi sebagai pusat pendidikan dan pengembang keagamaan khususnya pada masyarakat sekitar dan pada masyarakat luas pada umumnya.

Untuk program lain yang ada pada pesantren Shohibul Qur'an diantaranya: program pendidikan madrasah diniyah awaliyah, program pendidikan keterampilan (industri), program pendidikan dakwah, program panti asuhan, program Taman Pendidikan Quran (TPQ), dan program kesetaraan wajar dikdas salafiyah (2005-sekarang).

\section{PENUTUP}

\section{Kesimpulan}

Penyelenggaraan Pendidikan Pesantren Salafiyah Shohibul Qur 'an Kendari didasarkan pada tujuan untuk mendidik santri agar dapat menghafal ay at suci Alquran serta mengamalkan dalam kehidupan keseharian, menguasai ilmu agama, sains, dan teknologi serta mem- 
punyai tanggungjawab agama, bangsa, dan Negara, dan menjadi santri yang siap pakai dan professional yang memiliki kepribadian kuat dan tawaddu sebagai hamba Allah swt dalam kehidupan bermasyarakat, berbangsa dan bernegara. Berdasarkan tujuan tersebut kondisi penyelenggaraan pesantren salaflyah pada pondok pesantren Shohibul Qur'an terkait aspek pengelolaan (kiai/ustaz), sarana dan prasarana, dan sumber biaya belum memadai dalam keberlangsungan sebuah proses pembelajaran, khususnya insentif terhadap pengelola kiai/ustaz. Pada aspek sistem pembelajaran pesantren Shohibul Qur'an seperti masa pembelajaran, kurikulum, materi, metode, teknik evaluasi yang digunakan, dan peran serta program pesantren secara umum pelaksanaannya belum sepenuhnya mengacu pada ketentuan kepesantrenan shohibul Qur'an.

Respon masyarakat terhadap penyelenggaraan Pesantren Salaflyah Shohibul Qur'anKendari sangat apresiatif ini ditunjukan oleh pengetahuan, tanggapan, dan partisipasi masyakat terkait komponen-komponen yang ada pada pesantren baik dari segi metode pembelajaran yang gunakan, sarana dan prasarana, kurikulum, guru/ustaz, maupun pengelolaan pesantren. Selain peran pesantren yang berfungsi sebagai pusat pendidikan (TPA/TPQ dan madrasah diniyah) peran-peran lain yang tunjukkan oleh Pesantren Shohibul Quran secara kelembagaan telah melakukan kegiatan wajar dikdas, panti asuhan, pengembangan industri, serta bidang pengembangan kemasyarakatan seperti dakwah (pengajian, ceramah agama, dan tabliq) tidak hanya di dalam pesantren maupun di lingkungan pesantren, sebagai pengembang sumber daya manusia, seperti melakukan pembinaan pada kelompok-kelompok yang ada di masyarakat, memobilisasi masyarakat dalam perkembangan keagamaan, sebagai penyelenggara aktivitas keagamaan lainnya penerima zakat, infak, dan shadaqah, dan lain-lain.

\section{Rekomendasi}

Pesantren salafiyah sebagai lembaga yang menyelenggaran dan mengelola pendidikan berhak mendapatkan batuan material maupun non material terkait komponen-komponen kepesantrenan sebagai upaya menopang pertumbuhan dan keberadan pesantren salafiyah kedepan.

Perlunya acuan yang baku terhadap sistem penyelengaraan pembelajaran khusus kepesantrenan seperti masa pembelajaran, kurikulum, dan lain-lain bagi pesantren bersangkutan atau dalam lingkup sendiri.

Perhatian dan dukungan berbagai pihak sangat diperlukan terkait peran dan program pesantren sebagai upaya dalam mengeksiskan peran dan program tersebut.

\section{Ucapan Terimkasih}

Penulis mengucapkan terima kasih kepada semua pihak yang berperan dalam mensukseskan penelitian ini. Ucapan terima kasih kepada Kepala Balai Litbang Agama Makassar, Kepala Kantor Kementerian Agama Kota Kendari, Pimpinan dan pengasuh Pesantren Salafiyah Shohibul Qur'an yakni Bapak Muh. Safrizal, S.Ag,KiaiAbuHamid,IbuHidayatullah Wasiah, dan semua informan yang tidak sempat saya sebutkan satu persatu. Semoga kerjasama kita bermanfaat bagi pengembangan dan peningkatan kualitas pendidikan keagamaan di Indonesia.

\section{DAFTAR PUSTAKA}

2010. Rencana StalegisBadanLitbang dan Diklat Kementerian Agama 2010-2014. Kementerian Agama Badan Litbang dan Diklat.

Departemen Agama RI. 2003. Undang-Undang Republik Indonesia Nomor 20 Tahun 2003 tentang Sistem Pendidikan Nasional.

Departemen Agama RI. 2004. Panduan Teknis Pondok Pesantren Salaflyah. Jakarta

Departemen Agama RI, 2005. Pola Pengembangan Pondok Pesantren, Edisi revisi. Direktorat Jenderal Kelembagaan Agama Islam Direktorat Pendidikan Keagamaan dan Pondok Pesantren.

Jurnal Edukasi. 2006. Pendidikan Pesantren dan Budaya Damai. Jakarta: Puslitbang Pendidikan Agama dan Keagamaan Badan Litbang dan Diklat Departemen Agama RI.

Jurnal Edukasi. 2007. Diversiflkasi Pesantren dan Pendidikan Agama. Jakarta: Puslitbang Pendidikan Agama dan Keagamaan Badan Litbang dan Diklat Depag RI.

Makalah workshop peningkatan kapasitas pondok pesantren tg1 13 s.d 15 Mei 2009. Pedoman Pengembangan Kurikulum Pondok Pesantren Salaflyah. Jakarta: Hotel Milineum.

Madjid, Nurcholish. Bilik-bilik Pesantren. Jakarta: Dian Rakyat.

MTT, A. Malik. 2008. Inovasi Kurikulum Berbasis Lokal di Pondok Pesantren. Jakarta: Balai Penelitian dan Pengembangan Agama. 
Panduan Teknis Pondok Pesantren Salafaiah, 2004. Jakarta. Departemen Agama RI

-Profit Pondok Pesantren Shohibul Qur'an Kendari Sulawesi Tenggara Tahun 2010. Kendari: Pesantren Shohibul Qur'an

Yamin, Martinis. 2008. Desain Pembelajaran Berbasis Tingkat Satuan Pendidikan. Cet.2. Jakarta: Gaung Persada Press.

\section{Wawancara}

Kiai Abu Hamid (Pengasuh Pondok Pesantren Shohibul Qur'an). Wawancara. Di Pondok Pesantren Shohibul Qur'an. Selasa, 12 Oktober2010.

Hidayatullah Wasiah (Ustazah/pengurus santri putri). Wawancara. Di Asrama Putri Shohibul Qur'an. Rabu 13 Oktober 2010.

Muh. Safrijal, S.Ag (Pimpinan Pondok Pesantren Salafiyah Shohibul Qur'an). Wawancara. Di Pondok Pesantren Shohibul Qur'an. Selasa, 12 Oktober 2010. 